\title{
EIGHT
}

\section{Collection Development, Acquisitions, and Licensing}

\author{
Frederick W. Dingledy, Benjamin J. Keele, \\ and Jennifer E. Sekula
}

\section{LIBRARY MISSION, GOALS, AND RESPONSIBILITY}

S. R. Ranganathan's second law of library science: Every reader his or her book. ${ }^{1}$ Librarians should know the needs of the community they serve, and the library's collection should reflect and satisfy those needs. ${ }^{2}$

When building a collection-development policy for a law library, the second law means that one size does not fit all. Different categories of law libraries (academic, government, and private) have different types of users with different needs. Even libraries within the same category may serve multiple user groups. A government law library located in the heart of a major city will have collection requirements that may only slightly overlap with those of one located in a rural county. Law schools can range in size from three hundred students to over two thousand. Most law schools are affiliated with colleges or universities, but some are independent and cannot rely on a main campus library to provide easy access to important materials in other disciplines. A librarian may work in a boutique firm with ten attorneys or may be at a firm with over a thousand lawyers in multiple branch offices across the country-or the world.

Thus, there is only one guideline the law librarian must follow when deciding the composition of the library's collection: meet the users' needs. A good place to start is by deciding what the library's mission is. The mission is the library's foundation and the justification for its exis- 
tence. Everything a librarian will need to consider when developing the library's collection ultimately flows from it.

A law school library might have a mission statement that reads:

The fundamental mission of the Law School Library is to serve the educational and research needs of the Law School community.

A county law library that is open to the public might create a mission statement like this:

The mission of the County Law Library is to provide current, practiceoriented law and law-related information to attorneys, judges, other county officials, and members of the public.

A law firm library's mission statement will usually be much narrower:

The Law Firm Library serves the information needs of the firm, including its attorneys and paralegals, other staff members, and clients.

The mission statement is the broadest description of what the library does: what major groups of people does it serve, and what type of information does it provide? The mission statement will lead to the library's goals - a more detailed explanation of the objectives that the library must achieve in order to fulfill its mission. Once the mission and goals are established, they will serve as the framework the law librarian uses to decide what the library's collection policy should be. A law school library's goal statement might look like this:

The goal of the law library's collection-development program is to maintain and provide access to a collection of information resources that support law school programs, research, the curriculum, and the needs of library users. The primary objective of the law library is to select, organize, preserve, and make available to members of the law school community information resources that will aid them in these pursuits. The collection shall support the law school curriculum and faculty and student research, and meet the standards set forth by the American Bar Association and the Association of American Law Schools. As a secondary objective, the law library will select materials for use by the college community, the bench and bar, and other library users, in that order of priority.

A county law library might have these goals:

The law library's primary goal is to select, organize, and make legal information available to the county bench and bar, to other members of the local legal community, and to county residents. As a secondary goal, the library serves other members of the state bench and bar and residents of the state who do not live in the county.

A law firm library might use this goal statement: 
The law library's goal is to collect, maintain, and provide access to legal information necessary to satisfy the research needs of the attorneys and paralegals at the firm.

One of the most important things the library's goal statement must do is establish who the library's primary users will be, since a library's collection-development policy should clearly state that the library will acquire the resources those users need. In this case, "acquire" does not necessarily mean purchase. It can refer to licensing a digital resource or obtaining materials through interlibrary loan. A collection-development policy must acknowledge that the library's budget is not large enough to build an in-depth collection in every subject. Libraries that are open to the public will not be able to meet the needs of every user. Most libraries establish hierarchies among their patron groups, giving top priority to their primary users. A law school library centers its collection-development efforts on resources needed by the law faculty and students. A public law library focuses on the resources needed by the legal community and by the public in its jurisdiction. Since a law firm library is not usually open to the public, it will not need to identify who its primary users are-all of the firm's employees are primary, and there are no other users. If a law firm library participates in interlibrary loan and documentdelivery activities with other libraries, though, it should acknowledge that fact and be sure to mention that the library's users benefit by its participation.

The collection-development policy should identify who is responsible for implementing it. The director is ultimately responsible for all library activities, but developing and maintaining the collection may fall to another librarian. In some libraries, several staff members may share responsibility for collection development and maintenance. Each librarian might have different specialties or areas of interest, and the director may find it useful to assign responsibility for a subject to a librarian with expertise in that field. A director who chooses to have multiple staff members share responsibility should ensure that at least one person is responsible for covering the entire range of subjects the library collects. It may also be a good idea to allocate overlapping subject responsibilities between librarians. Multiple selectors in the same subject will result in a more complete array of collection decisions. In addition, while librarians are usually responsible for collection development, they don't have to be. A non-librarian film aficionado on staff might be an excellent person to select movies.

\section{TOOLS FOR SELECTING MATERIALS}

Librarians have several tools at their disposal to identify new materials to add to the library's collection. Some have been around for many years, 
while others are more recent additions to the collection developer's toolbox.

\section{Vendor Collection Profiles}

Many libraries order a large portion of their materials through vendors, usually library services companies such as YBP or Ingram. Vendors offer the convenience of ordering and handling paperwork from one company instead of multiple stores, and they often include discounts on purchases. For a small fee, vendors may also provide extra services, such as covering books with dust jackets before shipping them, saving time and effort for the library. A vendor can also notify librarians about publications and publishers they otherwise might not know about. Many government and law firm libraries may not find their collection large enough to warrant dealing with a library services company, but a firm library with multiple branches may want to consider one, especially if some of those branches are in nations where the acquisitions librarians do not speak the local language. Library services companies can help locate useful resources in those countries.

In the past, the library services vendor would mail an envelope full of slips identifying new publications available for purchase. This practice has been largely replaced by online interfaces for ordering publications, which typically feature announcements of new offerings. The library can customize these announcements by creating a profile-a list of categories of materials the librarians would like to know about. Each vendor may have a different system of categories. Some will use the Library of Congress call numbers, while others may use home-brewed subjects. When setting up a profile, consult the collection-development policy to be sure that every possible subject of interest is covered, keeping in mind that it is better to err on the side of overinclusion. Depending on the vendor's system, each selector may be able to create a "wish list," which can be useful if selections must be approved by a designated person. In that situation, the librarian in charge of collection development can decide which of the items on the lists to order. Ask the vendor if staff members' profiles can be set up so that everyone can see each other's profiles, as well as which materials were ordered. This can help guide future acquisition decisions as they learn which types of books on the wish lists are being purchased, and which are not.

\section{Publisher Catalogs}

A traditional method for identifying new materials to add to the library's collection is by browsing through publishers' catalogs. These are still an excellent way to find out what books are new and forthcoming, and will often describe the publisher's lineup farther into the future than 
the vendor announcements discussed above. Publishers still send out print catalogs-often whether the librarian requests them or not. Catalogs, however, have also migrated online. The librarian can go to most publishers' Web sites and browse their available selection, and can usually request e-mail updates listing new titles.

\section{Book Reviews}

Book reviews are another useful source for keeping up with new materials. Book reviews have a couple of benefits that make them a useful supplement to vendor sites and publisher catalogs. A review offers a more detailed, and possibly more objective, description of the book's content and intended audience, both of which may be hard to discern from vendor sites. A review might reveal that a book that sounded perfect from the vendor's promotional materials is actually intended for high school students. The disadvantage of using reviews is that they usually do not appear until several weeks or months after the publisher has given information on a book to vendors. Overall, though, reviews can give the librarian an idea as to whether a book is a worthy addition to the collection. Academic journals, the popular press, and news Web sites are all good sources of reviews.

\section{Demand-Driven Acquisition}

Demand-driven acquisition (DDA), also known as patron-driven acquisition, has gained momentum among libraries over the past decade. Put simply, DDA is a formal system that includes library patrons in the collection-development process. It is collection development's version of "just-in-time" production. ${ }^{3}$

There are several ways to implement DDA in a library. One method libraries frequently use is to tie DDA to the interlibrary loan (ILL) process; if a patron requests an item through ILL and it falls within a set of parameters determined beforehand, the library will instead order a print copy of the book and add it to its collection. ${ }^{4}$ Libraries may also choose to work with e-book vendors so that samples of e-books are made available to students through the library's catalog, and a certain amount of reading or checkouts by patrons will trigger an instant purchase of the e-book.

Some libraries that have experimented with DDA have found it to be a useful supplement to their collection-development techniques-Purdue University and Bucknell University libraries found that books they bought through DDA had higher circulation and use rates than those books acquired through traditional methods. ${ }^{5}$ Purdue also discovered that DDA titles often came from interdisciplinary fields that the library's acquisitions staff considered outside their normal responsibility. ${ }^{6}$ 
When implementing DDA, set out guidelines ahead of time as to what materials can be acquired. A price ceiling for each item is usually recommended for automated purchases - some libraries may choose $\$ 50$; some may go higher. An important consideration is what activity will trigger a DDA purchase. For example, the University of Florida and Florida State University's law libraries worked with a vendor to make a large selection of e-books in certain subjects available through their catalogs. If users checked an e-book out three times or read more than sixty pages from the book, then the libraries purchased the e-book for their collections. ${ }^{7}$

Libraries may wish to place limits on the types of materials that can be ordered through DDA, such as textbooks, which can be expensive and contribute little to the library's research mission but may be frequently requested by students. It may also be a good idea to exclude journal issues from DDA to avoid a piecemeal collection, or to avoid DDA purchases of serials altogether because of the ongoing cost of maintenance and upkeep. Libraries should make sure that DDA orders do not duplicate items already available to their patrons through other sources, such as blanket subscriptions to e-book services like NetLibrary (now EBSCOhost). ${ }^{8}$

If the library is worried about adding too many marginal titles, the DDA plan could also include a "yellow light" category of materials that require library approval before being acquired through DDA. If a library will automatically buy books under $\$ 50$, maybe it can create a "yellow light" for books between $\$ 50$ and $\$ 100$. That way, most materials requested through DDA are quickly acquired and in the hands of patrons, and the library can avoid spending money on unwise purchases.

Set a separate budget for DDA materials, especially in the beginning, to ensure that they do not unduly drain funds for items acquired in more traditional manners - at least until the library determines how well DDA is working. By the same token, it is a good idea to have a policy stating that librarians cannot use DDA as a way to get books that were rejected through other collection-development processes. ${ }^{9}$

\section{COLLECTION INTENSITY, SCOPE, GUIDELINES, AND CRITERIA}

Most libraries do not assign the same priority to all of the materials they would like to acquire. Libraries' budgets are too small to buy everything they want, and some items are more important to the collection than others. Consider creating levels of intensity within the collection-development policy for different subjects, from "minimal" to "research." The levels in a law school library's policy might look like this:

Current and anticipated courses, individual research projects, and other law school activities will be identified to help establish the degree of 
acquisitions intensity in specific areas. Depending on the area, the law library collects on the following levels:

- Minimal Level: An extremely selective collection that is very limited in both scope and depth.

- Basic Level: A selective collection that provides the user with a basic introduction to and outline of the subject. This collection includes introductory books such as hornbooks and nutshells, a few selected treatises, and only the most widely used specialized periodicals. Collection at this level will support only general research into the subject area.

- Instructional Level: A collection that adequately supports JD coursework and somewhat broader research into the subject area than is provided at the basic level. Collection at this level will contain the most authoritative multijurisdictional treatises, the most important treatises, several widely used specialized periodicals, and access to specialized digital information services and databases.

- Research Level: A collection that includes major published source materials required for independent scholarly research by law school faculty and students. Included are all significant multijurisdictional treatises, the best historical and current treatises, all widely used specialized periodicals, the major reference works in the area, significant nonlegal treatises that will aid in the understanding of the subject area, and access to specialized digital information services and databases.

- Comprehensive Level: At this level the library attempts to collect, as far as possible, all major works on a given subject, both current and retrospective. This collection will support the most rigorous, indepth research. Materials may be either print or digital, but need not be in both formats.

In most academic law libraries, the bulk of collection development will probably take place at the instructional or research levels. If the school or one of its faculty members is well known for expertise in a particular area of law, then the library may want to collect items under that subject at the comprehensive level. The library may acquire materials at the basic or introductory level for subjects rarely taught at the school and in which the faculty do little research - foreign jurisdictions, for example.

A law firm's library will probably have a very strong collection in any fields in which their attorneys specialize (a bankruptcy firm, for example, would have an excellent bankruptcy and debtor-creditor collection), with only a minimal or basic collection, if any, in other areas of law.

Government libraries will normally not have comprehensive collections in specific subjects. Instead, they will often have a strong collection of primary and secondary sources covering the law of their jurisdiction. 
There are exceptions to this rule, however; the library of a probate court will likely have a robust collection of materials on estate law.

Along with intensity considerations, the library's development policy should also address the collection's general scope and the types of materials the collection contains. A portion of a law school library's scope statement might look like this:

Most treatise acquisitions are in the area of American law. New treatises are selected in accordance with the priorities outlined in this policy. As a general matter, the library attempts to collect one copy of each multijurisdictional or federal legal treatise by reputable publishers that support the curriculum, or faculty or student research. The library will acquire all state continuing legal education materials; however, other materials designed exclusively for practitioners will be acquired very selectively. The library will consider the availability of treatises in databases available to its patrons when making acquisition decisions.

Acquiring materials published within the past three years is a much higher priority than acquiring retrospective materials. Generally, little attempt is made to purchase retrospectively, except for in specific subject areas in which there is a demonstrable need for historical materials, or areas in which there is special funding.

Print serials involve a commitment to ongoing costs, binding, and storage. The large number of law and law-related serials makes it impossible to purchase every title, and they are acquired selectively. The library will consider the availability of a journal title in databases available to its patrons when making a decision on whether to subscribe to it in print.

\section{The collection scope statement in a law firm may appear as follows:}

The collection consists of a variety of formats, including a balance of print and digital resources. It includes both current materials and, more selectively, historical materials as needed. Information resources are provided within the budgetary, space, and technological constraints outlined by the Library Committee and the firm's CEO. In all cases, acquisition of resources will take into account the research skills of and amount of use by attorneys and paralegals. The library will use interlibrary loan as a substitute for purchase for infrequently used titles.

A state law library's scope statement might read like this:

Generally, the library will collect primary legal materials from the federal government, U.S. territories, and the states. We will acquire secondary materials on a wide variety of legal subjects, especially practical materials that will be used by attorneys and citizens of the state. The library will maintain a comprehensive collection of this state's legal materials, both current and historical. The library will not acquire international law materials or foreign law materials.

The library will collect basic materials on the law of the United States and of the state in languages used by a significant minority of the 
state's population, but otherwise will only collect English-language materials. The law library relies heavily on interlibrary loan and document delivery for materials not within the scope of this policy.

The policy should also include guidelines that address issues such as cost, currency, language, format, and institutional priorities. If others must approve the policy-for example, the library committee in a law school or law firm, trustees in a county law library, or the chief judge and clerk of court in a court library - the guidelines will both explain and justify collection-development decisions. A law school library's collection-development policy may include the following statements:

- Current publications of lasting and scholarly value are given priority over retrospective materials.

- With minor exceptions, foreign language publications are not collected.

- Availability of materials online (e.g., Lexis, Westlaw, HeinOnline, or free Internet resources) or in other libraries through cooperative acquisition programs will be considered for infrequently used material and, in particular, for the laws of foreign countries.

- Duplicate copies are purchased for heavily used materials, and for items likely to be checked out indefinitely to a faculty member's office.

- In-depth materials for specific student research products, or for short-term faculty research projects, are not purchased unless the library's acquisition policy specifies collection development at the "research" or "comprehensive" level in that area. Such materials will be borrowed from other libraries as needed.

- Materials in support of the instructional and research needs of the law school faculty and students are favored over those for use by the rest of the university community, by the bench and bar, or by the general public.

Selection criteria also help the people responsible for collection development. Decisions to acquire or not to acquire an item are both collectiondevelopment decisions. Some criteria any type of law library might use include:

- Author and publisher reputation

- Significance of the subject matter

- Accuracy and timeliness of material

- Usefulness of title with respect to other materials already in the collection in print or digital format

- Appearance of the title in important bibliographies, lists, and other review sources

- Current and permanent value of the material

- Cost, including storage and maintaining currency 
- Frequency, substance, and quality of updating and supplementation

- Format

- If digital, terms of the license

- Availability of the material in other libraries

\section{STANDARDS AND ACCREDITATION}

The only mandatory collection standards for law libraries involve those at law schools accredited by the American Bar Association (ABA) and/or the American Association of Law Schools (AALS). The American Association of Law Libraries (AALL), however, has created advisory standards governing appellate court, state, and county law libraries.

\section{Law School Library Standards}

The ABA most recently revised its standards for law school libraries in 2005 to recognize the deepening connection between technology and legal information. In 2008, the ABA initiated another comprehensive review of its accreditation standards, which is still ongoing. Since the last revision, technology has become an even bigger factor, and space and budgets have become even tighter in many libraries. The proposed amendments may lead to some substantial changes to meet these challenges.

\section{Current ABA and AALS Standards}

The library must be an "active and responsive force" in the law school, and must have sufficient financial resources to support the institution's teaching, scholarship, research, and service programs. ${ }^{10}$

The library must have a "core collection of essential materials" accessible in the library itself, as well as a collection that satisfies the law school's curriculum and the educational, research, and service needs of its students and professors. The materials must also be current, complete, and in sufficient quantity or accessibility for faculty and student use. The library also has to create and regularly update a written collection-development plan, and provide sufficient space and equipment to access the collection. ${ }^{11}$ The appropriate mix of formats depends on the needs of the library and its patrons, but using only one format may not be enough. ${ }^{12}$

Libraries can enter into written agreements to share information resources if those agreements give faculty and students the necessary ease of access and availability to support the school's programs, but those agreements cannot be used to satisfy the core collection requirement. Schools cannot simply point their students to other law libraries for all of their research and education needs (not to mention that this would not 
endear the school to other members of their legal community). ${ }^{13}$ The standards do permit the library to use off-site storage for "non-essential" items, so long as those items are "organized and readily accessible in a timely manner." 14

Interpretation 606-5 provides much more detail as to what specific types of materials the library's "core collection" must contain. ${ }^{15}$ The core collection cannot consist entirely of digital materials, but a substantial portion of the core collection requirements may be fulfilled using digital resources. While the interpretations prohibit libraries from making the majority of their resources available online only, they do allow for a fair amount of flexibility to fit each school's particular needs.

AALS's bylaws address the law library's collection requirements in much broader terms. Section 6-8 states that the library must be "adequate to support and encourage the instruction and research of its faculty and students," and that it "shall possess or have ready access to a physical collection and other information resources" to meet the research needs of students and faculty, satisfy curricular demands, allow the proper training of students in research methodologies, and serve the school's special educational and research needs. ${ }^{16}$ As with the ABA rules, the AALS standards give libraries considerable leeway in meeting the overall requirements as they see fit.

\section{Proposed Changes to ABA Standards}

The ABA's Standards Review Committee is currently revisiting the accreditation standards for law schools. At the time this chapter was written, the proposed changes to chapter 6, covering libraries, were still in draft form. Some of the proposals are related to housekeeping-tasks like renumbering and moving some Interpretations. More substantially, the revised standards would require all libraries to include the U.S. territories' primary legal materials in their core collections. ${ }^{17}$

Other changes expand the flexibility libraries have when developing their collections. The revisions would still indicate that using one format for the entire collection may not be sufficient to meet the standard, and that schools must provide on-site access to materials. On the other hand, the proposed changes remove the language that states that the standards cannot be met solely by providing digital access. The new language would also allow libraries to provide a core collection through the sharing of digital and print resources, and would even permit the use of free databases as part of that core collection, as long as those databases are likely to remain free to the public. The proposed new language also says that the standard can be met through "reliable access" as well as ownership. ${ }^{18}$ 


\section{Public Law Library Standards}

In July 2005, AALL's State Court and County Special Interest Section (SCC-SIS) and the AALL executive board issued the Appellate Court Libraries and State Law Libraries Standards. ${ }^{19}$ The County Public Law Library Standards followed in July 2009. ${ }^{20}$ These are not binding in the way the $\mathrm{ABA}$ and AALS standards are for law school libraries; they are only suggested guidelines for a public law library's operation.

In their commentaries, AALL and SCC-SIS describe both sets of standards as recommendations to help provide a strong core law library collection. Each set includes a specific list of materials that AALL and SCCSIS consider to be the minimum requirements for the core collection, covering legal resources from the library's state, federal law, and national materials. They also take pains to make clear that these lists should be considered a collection-development floor, not a ceiling. Both sets of standards also state that cooperative resource-sharing agreements with other libraries within a "reasonable geographic area" will satisfy the standards, as long as staff are available to help users access off-site resources. Both sets of standards call for a mix of print and digital resources.

\section{FORMAT ISSUES}

\section{Digital Resources}

In law libraries, the term "digital collections" usually brings to mind enormous databases of case law, statutes, regulations, and secondary sources. ${ }^{21}$ Most of these materials were first published in paper or as microforms and were later digitized. As government and secondary publishers switch to digital publishing, more new materials are "born digital" and have no analog predecessor.

\section{Features}

A major advantage of most digital resources is the ability to search for specific words and phrases. Some databases use complex, proprietary algorithms to help researchers sift through massive amounts of text, while others offer little more than the ability to find a specific word. Examine all the different methods researchers can use for searching. Natural language searches, with the database's search engine doing much of the work, are more familiar and comfortable for many researchers. However, if these searches produce unexpected results, it is difficult to know precisely what terms were sought by the search algorithm. In those cases, carefully crafted Boolean searches permit more precise searching. Browsing through an index and similar subject-based listings can also be very useful, if the database offers such features. 
Evaluating Digital Products

Librarians are often responsible for teaching researchers how to use resources. It is unrealistic to expect a legal database to be as simple and intuitive as a Google search, but a product that is difficult to use will either go unused or require plenty of training. Librarians who regularly use databases may forget how intimidating and challenging an unfamiliar database can be for novices. As you test out a potential acquisition or watch a vendor demonstration, imagine how a digital resource will seem to new researchers. Will the navigation and resource names and symbols make sense? Are the tools for common tasks prominently labeled and easy to locate? Select a known document you want to retrieve, and see how many ways the database can lead you to it. Then choose a topic that is interesting to you and see how much relevant material you can find. Expect to hit some dead ends; they are probably obstacles your researchers will run into, too. Analyzing the user experience this way will help you decide whether the product is a good fit for your patrons and how you will teach researchers to use the product. If it will present challenges to your researchers, can you mitigate any problems through proactive training or just-in-time assistance from librarians?

Cost is, of course, always an important consideration, but for reasons besides the library's collections budget. Private and government law librarians have to justify expenditures for databases by showing how they contribute to the organization's mission, and must demonstrate that the product is being used in a cost-effective way. This makes cost-containment training crucial, and not just for researchers in the law firm or at the court. Academic librarians need to be aware of the expense of digital research and teach their students to develop cost-effective habits while still in law school.

\section{Accessibility}

It is fair to expect most online resources to be readable by Web browsers. Mobile devices, such as tablet computers, e-readers, and smart phones, are also often used to access resources. Are mobile-optimized Web sites or applications available for the product you are reviewing? WestlawNext, LexisAdvance, and Fastcase have apps for phones and tablets. WestlawNext also lets a user send documents to her e-reader for later review. Researchers use a variety of devices, so databases that can transfer content between devices and across operating systems are attractive.

Some databases, especially e-book collections, permit limited downloads or viewing, and place digital rights management (DRM) controls on users' downloaded copies. Others prevent printing or e-mailing more than a set number of pages. The vendors' desire to prevent unauthorized 
copying is understandable, but such limitations can also decrease the value of the resource. An e-book database that only allows researchers to download or print ten pages might be frustrating for those who like to make notes on their copies. A database of legal forms should let researchers download forms in an editable format so they can complete and prepare them for filing.

Use the process of evaluating digital resources for acquisition as an opportunity to talk with your core patrons about how they access digital information in their research processes. Ask them how they conduct their research and what features make their work better. In addition to informing librarians about what resources and research training their patrons need, such discussions also reinforce perceptions of librarians as knowledgeable and responsive legal information specialists.

\section{Perpetual Access}

Unlike print materials that the library purchases and then owns indefinitely, most digital resources are covered by license agreements. If you sign a license agreement to gain access to a digital product, you do not own it; you are merely renting it, and do not have the same rights as you would for a typical book. Under U.S. copyright law's first-sale doctrine, ${ }^{22}$ someone who buys a copy of a copyrighted work can sell the copy, lend it, or rent it. The first-sale doctrine is the legal basis for most library lending.

The first-sale doctrine does not apply to copies that are lent or rented, nor to licensed databases. What you can do with licensed content depends completely on the contract between the library and the vendor. The license may prevent you from printing or saving backup copies of the content, or sending copies of journal articles from a database to other libraries like you could from a print journal. The default rules contained in the Copyright Act are fairly friendly to libraries, but those rights can be signed away by license.

Another important aspect of ownership is continuing access. If you can no longer afford the digital product, you will likely lose access to all the information in that resource. On the other hand, if you had to cancel a subscription to a print law journal or a loose-leaf service, at least after the subscription ended you would still possess the issues and updates you had received. Additionally, many vendors are aggregators that license material from other publishers, and if that license ends, the vendors have no choice but to remove the content.

These scenarios are not inevitable, but they can only be prevented through appropriate provisions in the license agreement. Some vendors offer post-cancellation access (also called perpetual access or digital ownership), and it is an option that is worth watching for. Under these arrangements, the library owns a copy of the digital files that were in the data- 
base during the subscription term. The catch is that the files may not be provided to you in the same format or with the same user interface as those that you could access through an active subscription. Still, perpetual access is better than nothing - just make sure you understand how you will receive your content. Having a hard drive holding thousands of text documents or PDF files may not be especially useful to your researchers. You will probably need an access mechanism through a locally maintained portal, the vendor's Web site, or a third-party provider.

The University of Pittsburgh Barco Law Library faced this situation when the contents of a database it canceled arrived in several digital tape cartridges. The library recruited a computer engineering student to develop a basic user interface to provide access to the content. ${ }^{23}$ Companies exist that can build and maintain user interfaces for libraries. The cost of doing so will depend on what sort of features you want to offer your users.

Some vendors, such as JSTOR and Project MUSE, promise perpetual access to the digital content available to your library during the subscription period. Other publishers have contracted with Portico, a digital preservation organization that provides post-cancellation access to member libraries for a fee (but probably much less than the cost of a current subscription). On the other hand, perpetual access to print items requires continuing investments as well. Keeping everything in good condition and organized requires space, materials, and personnel, so be sure to include all access costs in your expense calculations.

\section{Microforms}

Poor microforms. Just a few decades ago, they were being hailed as the format of the future. Print books in libraries would move aside, replaced on the shelves by reels of microfilm, drawers of microfiche, and plenty of microform readers. Today, tell someone that the information they seek is only available on microform, and their reaction says that you may as well have told them they must journey to the deepest fires of Mount Doom.

Microform does have its advantages. It has a long life expectancy (around five hundred years for the current generation meeting international standards); it takes up very little space compared to print; and once the library has bought the microform, it is the library's to keep. Many libraries still have a large number of microform documents; in fact, a substantial portion of a law library's volume count may be in microform. Microforms also capture the original page images, giving the format an advantage over text-only databases when searching for some types of content, such as advertisements, maps, and charts.

That said, microform has a number of disadvantages as well. Microform can be a pain to read; it is not easily searchable, the way digital 
documents are, or as easy to browse as print materials. Microform readers are expensive, easily costing several thousand dollars each. Patrons may think twice about how crucial it is to use the resource if they are told it is only on microform.

A library might address microforms in its collection-development policy like this:

The library collects materials in microform primarily when:

The materials are infrequently used, and one of the following is true:

- The materials would take up a great deal of shelf space, were they in paper format, or

- The materials are not available in paper format, or

- Preservation in microform is superior to paper, or

- The cost of the materials in microform is significantly less than the cost of the materials in paper format.

In all cases, the library will consider the digital availability of the material-especially when in PDF - as an alternative to microforms. Digital information may be a cost-effective alternative to microform when the library is confident that the digital materials will be available indefinitely.

\section{PARTICULAR SELECTION ISSUES}

\section{Newsletters and Loose-leaf Services}

Newsletters can eat your budget alive, if you let them. They are often expensive and have limited usefulness beyond being a current awareness tool. Many libraries subscribe just to those newsletters that are routed to someone-an attorney in the firm, a judge, or a faculty member, for example-and renew a subscription only after verifying that it is still needed. Online alternatives to traditional print newsletters abound at various price points. Commerce Clearinghouse $(\mathrm{CCH})$ and BloombergB$\mathrm{NA}^{\prime} \mathrm{s}$ offerings may make sense for firms and schools with practitioners and faculty who research within the topics covered by those services. Lexis and Westlaw also offer current awareness notification features within their main products, and boutique legal news companies, membership-based groups such as the American Bar Association's various special interest sections, and nongovernmental organizations may provide low-cost or free newsletters for customers, members, or subscribers. For example, the American Society of International Law's semimonthly newsletter, International Law in Brief, covers recent developments in international law, and is e-mailed to subscribers (who do not have to be members) free of charge. 
A law firm's policy on newsletters might look like this:

The library only subscribes to newsletters that are being used by attorneys, paralegals, or staff. Every newsletter is reviewed annually to assess current use. Where possible, online subscriptions are preferred to print. BloombergBNA, $\mathrm{CCH}$, and other providers offer summaries of daily and weekly reports sent via e-mail links to full-text documents. Lexis and Westlaw also can be used to keep current.

Depending on the practice area and the needs of individual attorneys, an online subscription to a newsletter might include only highlights and summaries, or it could include access to the full text of each issue. Attorneys are encouraged to investigate current awareness options offered by associations and organizations to which they belong.

The burgeoning expansion of the administrative branch of government in the early to mid-1900s created the need for lawyers to find statutory, administrative, and judicial materials in one place. Enter the loose-leaf service, which gathered these disparate forms of law on a given subject into one set, and often included editorial commentary and extensive indexing in a comparatively compact, easy-to-update package. Two of the biggest loose-leaf publishers, $\mathrm{CCH}$ and BloombergBNA, each offered dozens of titles that were once a print mainstay in all types of law libraries. Both companies have shifted and modernized their loose-leaf content for online consumption.

Whether a library chooses to continue to subscribe to print loose-leafs or to online versions (or both) depends on its resources. Factors to consider include subscription costs, shelf space (some sets, especially those covering tax and labor, are quite large), the availability of staff to file updates, and how the library's users prefer to research. Regarding this last issue, it may be difficult to migrate to online services if the lawyers in your firm, judges in your court, or faculty in your school insist on using the print. Old habits sometimes die hard, so seek input from users, and use online trials to evaluate the advantages and disadvantages of various products. (See "Evaluating Digital Products," within this chapter.)

\section{POPULAR READING}

Most libraries have a casual reading area that includes newspapers and magazines. Typically, a library might subscribe to local papers and national publications such as the New York Times, Washington Post, Los Angeles Times, and the Wall Street Journal. Although these are all available online, many readers still prefer the tangible pages of newsprint. The library likely will offer the local and state legal newspapers, The American Lawyer, Legal Times, and the National Law Journal.

The magazines to which you subscribe should be those that your patrons want to read. You might offer the popular newsweeklies; business, 
entertainment, and sports magazines; and policy-related magazines. Depending on your patron base, you might also include technology, fitness, or local interest publications-whatever appeals to your users. If you don't know what they'd like, ask them! Magazines are inexpensive, and they give the library a lot of goodwill for little money.

Many law libraries have popular book collections that include fiction and mystery; current events, biography, and history; and humor. Keep the book jackets on the books; they attract readers and make for eyecatching displays. Like popular magazines, these inexpensive additions to your collection are a great value. Some libraries also offer a popular film collection tailored to their core user groups. Selections might range from the latest TV dramas and award-winning films to classic comedies and children's features that users can take home to their families. ${ }^{24}$

\section{Reserve}

Many libraries, especially those in law schools, have a reserve collection that remains under the control of library staff. Items within this collection are usually subject to shorter circulation periods and stiffer overdue fines in order to facilitate accessibility. Patrons may be permitted to browse the shelves (open reserve) or may have to request items from a staff member (closed reserve). The access method you choose depends on how closely you want your reserve collection to be monitored, as well as other considerations, such as your physical layout and availability of the staff to retrieve materials.

A law school library's reserve collection usually has materials placed there by faculty for classes or general use, heavily used items such as study guides, and items that are at a higher risk of theft. The collection may include practice and continuing legal education titles from the home jurisdiction, hornbooks and nutshells, and audiovisual materials. Some libraries keep current issues of law journals on reserve, too. The collection should be dynamic; materials no longer needed on reserve should be moved to the open stacks.

\section{Reference}

Most libraries' reference collections have shrunk significantly due to the ubiquity of reliable resources online. Information that used to be found only in a print directory may now be available on a Web site for free or for a nominal subscription fee. The collection policy should recognize that reference materials include information in both print and digital formats, and that the "reference collection" provides users with current, useful, and authoritative resources for frequently researched issues. Some libraries will include every reference source in a discrete collection that typically is located near the reference desk, while others spread some 
of their reference books throughout the library. An institution that takes the latter approach may have a policy as seen in table 8.1.

\section{Foreign and International Law Collections}

"International law" refers to the law between nations, such as treaties on every topic from the environment to extradition, the decisions of international courts, and the activities of intergovernmental institutions like the World Trade Organization. "Foreign law" is the law of any jurisdiction that is not your own. The size of a law library's foreign and international law (FIL) collection may range from microscopic to an entire floor or wing, and in some cases may be in a separate branch of the library. FIL materials are typically much more expensive than their domestic counterparts, and can be a real challenge to buy and maintain on a limited budget.

You will need to decide whether to collect FIL materials at all, and if so, whether to do so broadly, deeply, or both. ${ }^{25}$ For example, a library in a law firm with a significant international presence may provide attorneys with a thorough collection of primary and secondary materials covering the countries and areas of law in which the firm or its clients conduct business, plus a smattering of general FIL materials. A law school may develop a broad foreign law collection covering each individual country's legal system (books such as Introduction to German Law and The Nigerian Legal System), and only purchase additional materials for those countries and legal systems that faculty are actively teaching or researching. That same library may also offer a collection of materials on international law that is both broad and deep.

Whichever you choose, investigate online options and periodically revisit those options as new Web sites are launched and existing ones decay or disappear. Documents from intergovernmental organizations (such as the United Nations and the European Union) and some countries are available online at no cost, but secondary materials generally require a subscription for access. Some products cover single jurisdictions, such as Chinalawinfo, while others, like vLex, are multijurisdictional. Pricing varies widely, as does the quality of translations, when available.

By being selective and creative, the library can stretch its budget. Carefully investigate potential purchases, avoiding books that are nothing more than collections of previously published articles you already own or compilations of freely available primary documents. Talk with other law libraries in your region to see if there is any interest in cooperatively collecting materials, perhaps by agreeing to split jurisdictional responsibilities. For instance, one library could collect European law, while another collects Asian law. Above all, closely monitor your firm's prac- 
Table 8.1.

This policy offers guidelines on which materials should and should not be included in the library's reference collection.

Works shelved in the reference collection. These include those used frequently by librarians and a wide variety of patrons. The reference collection will comprise:

1. Authoritative general reference works, including:

- Well-regarded, general-purpose nonlegal works, such as general dictionaries, encyclopedias, and biographical dictionaries and encyclopedias.

- General-purpose legal works, such as Black's Law Dictionary and American Jurisprudence $2 d$.

- Selected style, grammar, usage, and citation guides pertaining to law and general writing.

2. General reference works pertaining to the state, including frequently used works specifically relating to the court system and political science.

3. Current statistical resources.

4. Whether they are general purpose or subject specific, the current editions of statistical resources are shelved in the reference section.

5. Current general legal bibliographies.

6. Subject-specific and general-purpose directories.

Reference-type works shelved in the stacks. These include works that are easy to shelve in a specific category, and those that are normally accessed and used with other works on that subject. Reference-type materials shelved in the stacks include:

1. Subject-specific works, including dictionaries and encyclopedias, and

2. Subject-specific bibliographies.

Prior editions. The library will only keep the newest edition of a reference work in the reference collection. Prior editions are kept selectively, and will be shelved in the stacks. Superseded reference materials retained in the stacks indefinitely include:

1. Publications with a significant change in coverage between editions.

2. Selected biographical materials.

3. State materials.

4. Fact-based annual publications, such as almanacs. 
tice areas or your faculty's research interests, and acquire only high-quality products that fit those needs.

\section{Annex and Remote Collections}

Some libraries maintain annex or remote collections within the larger institution, such as a job-hunter's library in a law school's career placement office. A library that provides materials for other locations - whether it is a judge's chambers or a legal writing department-should maintain some control over those items. Process the materials through the library: use the library stamp, label them to indicate their location, and check them out to the unit or office in which they are kept. Purchase and manage online subscriptions as well. For password-protected services, set up or keep a copy of the log-in credentials.

\section{Gifts}

Beware of patrons bearing gifts. As harsh as that may sound, the truth is that donors rarely read a collection-development policy before making a tangible donation. Your policy should include a statement on gifts, including the right to refrain from accepting ones that don't conform to the library's selection parameters.

Accept only those donations that you know will be of interest to the library, and refuse up front those that will not (as opposed to accepting all gifts and sorting them out after the fact). If a patron calls to inquire about a donation or stops by to drop one off, explain what parts of the gift you can and cannot accept. If, despite this, you are given something that doesn't fit the collection, be clear that you will not add it. Offer the donor alternatives if you have any, such as making the item available to students on a "free books" cart. This proactive approach will reduce the number of donors who return to "visit" their gifts, only to find that they were disposed of without ever touching a shelf.

Any donation that fits within the collection's scope should be processed and added to the library's holdings. Commonly, a bookplate is affixed inside (or a sticker might be placed on the front or back cover of a DVD) indicating who donated the item, unless anonymity is preferred. You can choose to include donation information on the item's record in the catalog: information about the gift can be detailed in the staff notes, and a small notation can appear in the public view if desired. Remember to send the donor an appreciative acknowledgement of the gift. If the donor asks you to appraise the value of the gift, politely say that you cannot. You may, however, refer the donor to professional appraisers.

Here is an example of a collection-development policy's statement on gifts: 
The library encourages gifts of useful materials. Before accepting such gifts, the library will request a list or general statement of the materials offered. The director of the library is responsible for accepting all gifts and will only accept those materials that conform to the selection guidelines or if the director finds them useful.

The library will not accept gifts with conditions as to their disposition or location except by express permission of the director. The director retains the right to determine the disposition of the materials at any time and in any manner deemed appropriate.

The library will not appraise the value of gifts for tax purposes. However, the library may assist a donor in obtaining prices located in catalogs of second-hand dealers or procuring the services of a professional appraiser.

\section{Special Collections}

Some types of special collections begin with a gift, but on a grander scale than usual. A faculty member, prominent attorney, or esteemed jurist or statesperson might retire and donate a package of collected notes, books, manuscripts, trial documents, photographs, or other materials to a library. In the best circumstance, the donor and receiving library will have discussed and negotiated the transaction before the actual handoff, so the library can prepare for staff and space considerations tied to processing the materials and determine where the collection will ultimately be located and how and to what degree patrons will access it.

The rare book collection, another type of special collection, is most commonly found in academic or large court libraries. Rare book collections may be themed (such as those which reconstruct the libraries of notable historical figures) or not, but in all cases will require specific ambient conditions and other long-term preservation accommodations. The process of selecting and caring for rare books is both an art and a science, and preferably should be carried out by someone with a background in it. If you want to build a rare book collection but no one on staff has any experience in the area, consider investing in special classes or training. It will pay off in the long run in terms of well-reasoned purchase and access decisions and proper display and maintenance techniques.

Either of these types of special collections, archives or rare books, may require hundreds or thousands of hours of staff time to organize, prepare, and catalog the materials, and in some cases may necessitate remodeling or adding on to the library. Hardware, software (off the shelf or custom-designed), and technological expertise may be needed if the materials will be digitized or hand-indexed. In return for these significant investments, the library preserves information that otherwise could be 
irretrievably lost, and receives the prestige of holding a completely unique collection that may attract researchers from all over.

\section{Lost Materials}

Sadly, sometimes books disappear. A library typically will declare an item to be lost when it has been off the shelf for a certain span of time without being checked out, and it cannot be located. Some libraries define an item as lost when it has been gone for three or four months, while others may wait as long as a year. Occasionally, a patron may confess to losing an item as well.

Decisions about replacing a lost item should be made using the selection criteria set forth in the collection-development policy. You might assume that if a book was selected pursuant to the development policy, it should be reselected under the same criteria. However, don't automatically replace a lost item; instead, determine whether you still need it. Factors to consider include:

- the age of the item,

- circulation information, if available,

- whether you have additional copies in the collection,

- the importance of the item to your collection and to the topic in general,

- if an older work, whether it imparts a historical perspective that might be of value to researchers, and

- replacement cost.

If an item is no longer in print, the library may need to search both new and used book dealers' Web sites to locate a replacement.

\section{WEEDING, UPDATING, MONITORING}

\section{Weeding}

Judicious and systematic discarding of certain materials is important for the health and usefulness of any collection. The decision to weed (remove items from) a collection can depend on a number of factors. The most common of these are space issues and financial constraints. Weeding frees up shelf space to make room for materials that are more germane to the purpose of the collection. Likewise, the cancellation and removal of items that have an ongoing cost-such as loose-leafs, journals, and heavily supplemented treatises-makes fiscal room for materials that the library places a higher value on.

Even libraries that enjoy ample space and an adequate budget benefit from periodic weeding. Just because a library has the space to keep each 
item it has ever purchased does not mean that it should. Clearing the unused, unneeded, or no longer useful materials from the collection allows users and librarians to more easily find relevant items. ${ }^{26}$ The perfect treatise for your patron's needs might be buried among multiple copies of every edition of Income Taxation of Individuals in a Nutshell dating back to 1972 and thirty-five volumes of an out-of-date copy of RIA's Federal Tax Coordinator, but who could find it?

Another benefit of regular weeding - collection pruning, if you willis that it will prolong the time before there is no room to jam another book on the shelf, triggering a massive, all-hands-on-deck collection purge. A trimmed collection is a more agile collection, making stacks shifts (spatial adjustments of materials due to growth) a more pleasant undertaking for staff.

Finally, weeding provides one additional benefit: walking the stacks and examining the collection keeps librarians in touch with what the library owns and where various topics are physically located. ${ }^{27}$ Some libraries even ask new librarians to weed or shelf-read part of the collection just for this purpose. The alert librarian might notice if a section of the collection seems underdeveloped or overemphasized, and may uncover works that are missing, misshelved, or that should be classified elsewhere.

The collection-development policy should include the library's practices regarding weeding. ${ }^{28}$ Items that law libraries typically weed include multiple copies of infrequently used materials (such as those old Nutshells), superseded replacement volumes of current works, substantially incomplete runs of journals in peripheral subject areas, and loose-leaf services to which the library no longer subscribes.

Depending on space availability, a library will likely keep superseded volumes, supplements, and pocket parts of the United States Code and its own state laws. To avoid confusion, superseded materials often are shelved in a different location than current ones, and should be prominently marked "superseded."

Materials that are available online, especially from the publisher or an aggregator like EBSCO, are also candidates for removal. However, when evaluating whether to cancel and withdraw print in favor of online access, consider the following questions:

- When the contract with the vendor ends, will access to some or all titles be lost, or is there a provision for permanent access rights? How is post-cancellation access provided? (See "Perpetual Access" within this chapter.)

- In the case of serials, is the online product subject to embargos of recent issues, and if so, can the material be found elsewhere? For example, a vendor may not provide access to the latest volume of a law review, but Lexis and Westlaw generally do. Does the vendor 
offer a complete run of the title, and if not, are you able to retain the print you already own to fill in the gaps? 29

- Do your patrons have a strong preference to use certain titles or types of materials in print or online? Note that this should not necessarily be the decisive factor when considering whether to cancel print in favor of online access. People tend to adapt when faced with the need to do so.

Even a digital product chosen to replace print is not immune from future weeding. Monitor it using the criteria discussed in the next subsection, and if it is no longer useful to your patrons, cancel your subscription.

Many librarians cringe at the thought of tossing withdrawn materials into the recycle bin. While much of what you weed will not be of use to anyone, you may be able to donate some items to charities that accept books for resale or for stocking libraries in remote, underserved areas around the world. Many libraries, especially government-affiliated ones, may have specific procedures to follow when disposing of weeded materials, so check those first. If space is your primary motivator for weeding and you think some of the materials might still have some life left in them, consider temporary or long-term off-site storage. With this sort of halfway-house setup, you can watch for items that are requested repeatedly. These would be obvious candidates for returning to the main stacks. If you opt for off-site storage, remember to weed that collection once in a while, too.

\section{Updating and Monitoring}

For a long time, legal publishers believed that the philosophy of "if you build it, they will come" 30 would also apply to librarians: "If you sell it, they will buy." This was generally true until the late twentieth century, when updating costs started to spike. Faced with static or shrinking budgets, libraries began deciding not to acquire every update on the market.

Whether a library chooses to receive every update to a title depends on its budget, its philosophy on updating, and the update's content. To some librarians, the integrity of a publication is compromised when it lacks the most recent information; others skip purchasing updates for certain titles, especially if the update does not include substantive changes to the text, but instead, only citations to newer court decisions.

In deciding whether to update a certain title, determine how useful the item will be if it is not updated, and whether researchers will be harmed if they do not have the current update. In fact, during this process you may find that you do not need the title at all. (See "Weeding" as mentioned within this chapter.) Some items are logical targets for nonregular updates, such as a title on trial practice. Each of the publisher's annual updates may contain very few noteworthy changes, since topics 
such as opening statements, closing arguments, witness examination, and so on are likely to remain substantially the same over the short run. Such a work would probably not suffer in terms of usefulness if updated only every two to three years. Always keep users informed, and include a notice where the supplement would normally be found that the update in the book is not the most current one available.

As the faculty changes in a law school, and practice areas shift in a firm, the library's collection will evolve over time. Most legal publications have ongoing costs, so frequently review your collection policy and subscriptions. The following law firm policy statement reflects the dynamic nature of collection development, and the need to review the collection and seek input from library users.

In order to provide attorneys and paralegals with the information that they need, and to adhere to the library's budget, the library will:

Monitor changes in practice areas

- Add to the budget for titles in new practice areas

- Cancel subscriptions for titles no longer being used

Continuously review subscriptions

- Before renewal, ask attorneys in the practice area if they still need the item

- As supplements are received, verify that the item is still needed

- As attorneys are added to routing lists, add more subscriptions as needed

Identify little-used but still-needed titles

- If available via interlibrary loan or online, consider canceling

- Review the need for continuous supplementation; alternatives include occasional updates, or periodic purchase of replacement sets

Review current awareness routing

- Review number of copies requested

- Change number of subscriptions as appropriate

- Compare e-mail and print subscriptions

\section{COPYRIGHT AND LICENSING}

Digital resources and license agreements are almost inextricably intertwined. This is primarily due to the confluence of copyright law and digital technologies. While equipment can enable the manufacture of infringing copies of paper books and journals, it would not be very convenient to do so. Digital files, on the other hand, can be perfectly copied 
quickly and easily. This difference has led vendors of digital resources to prefer licensing, instead of outright selling, their products to libraries.

As mentioned within this chapter (see "Perpetual Access"), copyright law is fairly generous to libraries and enables them, under certain circumstances, to make copies for their patrons. For instance, the section 108 library exception expressly authorizes libraries to make single copies of some resources for research purposes. ${ }^{31}$ The first-sale doctrine, as mentioned within this chapter, permits libraries to lend copies that they own. Additionally, libraries rely heavily on the fair-use doctrine, a broad defense that may allow copying when social interests outweigh those of the copyright holder.

License agreements override these default copyright protections, so when evaluating one, see what duplication it authorizes, and what it does not. Ideally, the license will acknowledge and maintain the library's rights under the fair-use doctrine and other statutory provisions. You should read all license agreements closely, but be especially careful with provisions covering authorized access and copying. Does the definition of an authorized user cover all the categories of researchers who come to your library? If you have a professor or attorney who prefers articles to be printed and routed to her, does the license have language that clearly authorizes that? You do not have to accept the vendor's form contract. Write your changes on the agreement, initial them, and send it back. The vendor may resist some amendments, but it cannot hurt to negotiate.

Avoid license provisions that seek to make your library liable for any infringement that researchers may commit. It is unreasonable to expect all researchers to perfectly comply with the publisher's interpretation of copyright law. The precise boundaries between infringing and permitted duplication are unclear and contested. ${ }^{32}$ Experts do not agree on the exact rules, so it should come as no surprise that sometimes researchers, out of ignorance, thoughtlessness, or misunderstanding, make infringing copies. It is impractical to expect librarians to closely monitor patron use of resources, and even if it were feasible, too much monitoring would infringe on researchers' privacy interests. Libraries can, and should, take reasonable measures to educate users about their rights and obligations under copyright law and to mitigate infringement, but they should not be responsible for patrons' actions.

Licenses cover many other matters than copyright. Check whether the vendor provides any guarantees that it will keep the database and all of its content online. If the database is down for an extended period of time or a significant amount of content disappears, you should have an option to cancel the subscription early or be reimbursed for the lost access. Do not let vendors disclaim the implied warranties of merchantability and fitness for a particular purpose. These warranties give you important protections if the database changes and is no longer useful to you. Many contracts will specify that they will be interpreted under a particular 
jurisdiction's laws. You will probably prefer that the contract be interpreted under your state's laws, and your organization may have a policy against contracts that apply the laws of another jurisdiction, especially if you work for a public institution.

Also, be sure that appropriate privacy protections are included for your researchers. Both vendors and libraries benefit from aggregated usage data, but records on each individual's research should be retained for a limited time and, ideally, remain under the control of the individual. WestlawNext and Lexis Advance, for example, keep research trails for each user, but the trails eventually expire unless the user saves them. Records that are retained should be kept confidential. State laws often shield library patron records, but they may not apply to private vendors' databases, so the same rules should be set out in contracts. ${ }^{33}$

\section{DIGITIZATION PROJECTS}

Aside from leasing and purchasing digital resources, libraries can build their own digital collections. These efforts come in many varieties and are a locus of innovation in academic law librarianship. The least technologically demanding of these types of projects is creating a digital repository of the law school's faculty scholarship and journals, or an online brief bank for a firm's attorneys. Most of these documents have already been digitized, so assembling such a collection generally requires acquiring and cleaning up the appropriate files, ascertaining intellectual property rights, and then loading them into a vendor-provided or open source digital repository platform. A more ambitious collection could involve digitizing materials that thus far only exist in analog format. Institutional archives, court records, records relating to local legal history, and faculty papers are good candidates for local digitization projects.

The costs of local digitization projects are mostly due to personnel and equipment, because the materials to be digitized are either readily available to librarians or, in the case of law journal articles, relatively inexpensive. You may need to invest in digitization equipment and software. What you will need depends heavily on the materials you wish to digitize and the access features you wish to provide, such as search and indexing. Digitization work can be outsourced to specialized vendors, and your project may benefit from the economy of scale that some of these vendors can achieve.

You will need some sort of public access platform. Vendor-hosted platforms are dominant in the law library market at present. Open source platforms are available, but require qualified staff to install and maintain both the servers and repository software. Law libraries have successfully implemented both vendor- and self-hosted repositories, either independently or in cooperation with university library systems. ${ }^{34}$ 
Digitization projects can easily mushroom into an unmanageable amount of work, so it is important to add a section on local digital collections to your library's collection-development policy. It is better to start small and set achievable goals. Once those are accomplished, your goals can become more ambitious. For example, you can expand the scope of your faculty publications to those written by adjunct professors and faculty who used to teach at your institution, but later left. You can move from journal articles to book chapters, pieces written for the popular press, congressional testimony, drafts that have been posted on the Social Science Research Network, or lecture notes. Perhaps the library will dive into multimedia, collecting images, audio recordings, and video recordings of lectures and conferences held at the school. Such an effort would present a new host of challenges, compared with collections that are predominantly text. You might need additional editing software or a new platform to preserve and provide access to the content, and you may need to hire a qualified vendor to handle some of the work.

To keep digitization projects manageable and to justify the expense, set criteria for what will be included. Assuming you are not planning a massive quest to digitize everything in your library's collection, good candidates for projects will have a defined scope, require relatively little permission collecting, fill a niche, and align with institutional strengths.

\section{INTERLIBRARY LOAN AND CONSORTIA}

No library can own every bit of legal information. Fortunately, libraries share with each other. Through the interlibrary loan system, libraries can obtain materials for researchers that are not in their own collections. This frees you from worrying about items that will rarely be accessed. You do not need to buy it if another library will lend it to you the few times you need it.

Interlibrary loan is not a panacea, of course. Libraries decide what parts of their collections they are willing to lend to other libraries. If you are hoping to borrow a current casebook, a popular movie, or a rare or fragile item, you will probably have a difficult time finding a library that will mail it to you. For those kinds of items, you should plan to purchase them or send the researcher to the other library to access the resource onsite. If a user's needs can be met by a scan or photocopy, then you are more likely to have the request filled. Additionally, license agreements for digital materials can sometimes limit interlibrary lending (another reason to carefully read and negotiate your licenses).

Interlibrary loan requests highlight holes in your collection, so use them as a tool to find weaknesses that can be remedied and to predict topics for which you are going to see more interest in the future. ILL statistics constitute a useful set of data that, along with patron input and 
your library collection-development policy, can help you choose worthwhile purchases. ${ }^{35}$ For example, if a book is requested for interlibrary loan several times by different researchers, that is a strong indication that there is enough demand to justify a purchase. In 1978, the National Commission on New Technological Uses of Copyright Works (CONTU) issued guidelines for copies of articles made to fulfill interlibrary loan requests. ${ }^{36}$ These guidelines include what is called the "suggestion of five": a library can request five copies of articles from a given periodical in a calendar year without worrying about copyright infringement. This is not a strict rule, and more than five copies might be fine, but if you are requesting more than five articles from a journal in a year, consider a subscription.

Purchases through library consortia are another way libraries share resources. Through consortia, libraries pool their funds to purchase or license materials that would not otherwise be affordable. Such acquisitions are shared among all the members, so in addition to understanding any licenses with vendors, make sure you understand the relationships you will have with other member libraries. Joining a consortium is essentially another collection-development decision. Use the same tools and information to decide whether spending funds on a membership is a good value for your library and will give you access to materials that are in step with your collection-development policy.

\section{CONCLUSION}

A law library is designed to meet the needs of its present and future researchers. To cultivate a collection that serves their patrons well, law librarians must select relevant, authoritative materials in appropriate formats. This means choosing from a wide variety of options while carefully managing a budget.

With a clear collection-development policy, librarians can make principled decisions that best use the library's acquisition funds. The development policy is an important document that should not be allowed to ossify into a relic of obsolete practices. Pay close attention to changes in publishers' offerings and your patrons' research needs, and use that information to regularly reevaluate and revise the policy. This will help your library's collection meet the aspirations of Ranganathan's second law by providing every reader his or her information source.

\section{NOTES}

1. S. R. Ranganathan, The Five Laws of Library Science (Bombay: Asia Pub. House, 1957), 9. 
2. Richard E. Rubin, Foundations of Library and Information Science (New York: NealSchuman, 2000), 251.

3. Jennifer Perdue and James A. Van Fleet, "Borrow or Buy? Cost-Effective Delivery of Monographs," Journal of Interlibrary Loan, Document Delivery and Information Supply 9 (1999): 24.

4. See, e.g., Perdue and Van Fleet, "Borrow or Buy?"; Kristine J. Anderson et al., "Buy, Don't Borrow," Collection Management 27 (2002): 1.

5. Anderson et al., "Buy, Don't Borrow," 9-10; Perdue and Van Fleet, "Borrow or Buy?" 24-27.

6. See, e.g., Anderson et al., "Buy, Don't Borrow," 5, 7.

7. Sarah Pearson, Erin Gallagher, and Edward Hart, "Seminoles and Gators: Can Shared Patron Driven Acquisitions of EBooks Overcome the Rivalry?" Presentation at the annual meeting of the Southeastern Chapter of the American Association of Law Libraries, Clearwater Beach, Florida, March 22-24, 2012.

8. Ibid.

9. Ibid.

10. Standard 606, 2011-2012 Standards and Rules of Procedure for Approval of Law Schools, dards.html.

11. Standard 606, 2011-2012 Standards and Rules of Procedure for Approval of Law Schools.

12. Interpretation 606-2, 2011-2012 Standards and Rules of Procedure for Approval of Law Schools.

13. Interpretation 606-3, 2011-2012 Standards and Rules of Procedure for Approval of Law Schools.

14. Interpretation 606-4, 2011-2012 Standards and Rules of Procedure for Approval of Law Schools.

15. Interpretation 606-5, 2011-2012 Standards and Rules of Procedure for Approval of Law Schools.

16. "Bylaws and Executive Committee Regulations Pertaining to the Requirements of Membership-The Association of American Law Schools," http://www.aals.org/ about_handbook_requirements.php.

17. "Standards Review, April 27-28, 2012," http://www.americanbar.org/content/ dam/aba/migrated/2011_build/legal_education/committees/standards_review_

documents/april2012/20120404_april12_src_meeting_materials.authcheckdam.pdf, 71, 73.

18. "Standards Review, April 27-28, 2012," 71-73.

19. "Appellate Court Libraries and State Law Libraries Standards," http:// www.aallnet.org/main-menu/Leadership-Governance/policies/PublicPolicies/policycounty-standards.html.

20. "County Public Law Library Standards," http://www.aallnet.org/main-menu/ Leadership-Governance/policies/PublicPolicies/policy-county-standards.html.

21. A useful article on print and digital collection development is Michelle M. Wu, "Why Print and Electronic Resources Are Essential to the Academic Law Library," Law Library Journal 97 (2005): 233.

22. 17 U.S.C. $\$ 109(2006)$.

23. Sallie Smith, Susanna Leers, and Patricia Roncevich, "Database Ownership: Myth or Reality?" Law Library Journal 103 (2011): 233.

24. If you do choose to collect movies, evaluate your willingness to lend them through interlibrary loan-they are wildly popular. If you want to ensure that your movies are available for your users, update your lending policy to reflect that you won't loan them through ILL, and consider automatically deflecting the requests to save staff processing time.

25. For discussions of the realities of putting together an FIL collection and considerations to take into account when doing so, see Holger Knudsen, "Collection Building: Foreign, Comparative and International Law in Print," and Marylin J. Raisch, 
"Shaping Electronic Collections in Foreign, Comparative and International Law," both in The IALL International Handbook of Legal Information Management, ed. Richard A. Danner and Jules Winterton, (Surrey, UK: Ashgate, 2011).

26. Vicki L. Gregory, Collection Development and Management for 21st Century Library Collections: An Introduction (New York: Neal-Schuman, 2011), 120.

27. Joyce Saricks, "At Leisure: The Lessons of Weeding," Booklist 108 (2011): 43.

28. For a practical example of how to plan and implement a systematic collectionweeding project, see Amy K. Soma and Lisa M. Sjoberg, "More than Just Low-Hanging Fruit: A Collaborative Approach to Weeding in Academic Libraries," Collection Management 36 (2011): 17.

29. For more information about cancellation and retention issues pertaining to serials, including implications of different digitization scenarios, such as the use of inadequate preservation-quality standards and converting image-intensive sources, see Roger C. Schonfeld and Ross Housewright, "What to Withdraw? Print Collections Management in the Wake of Digitization," Ithaka S+R, September 29, 2009.

30. Field of Dreams, directed by Phil Alden Robinson (Los Angeles, CA: Gordon Co., 1989).

31. 17 U.S.C. $\$ 108$ (2006).

32. Melville B. Nimmer and David Nimmer, Nimmer on Copyright (New Providence, NJ: Matthew Bender, 1963, 2012), § 13.05.

33. There is plenty of worthwhile reading on libraries, copyright, and licensing. Two solid options are James S. Heller, Paul Hellyer, and Benjamin J. Keele, The Librarian's Copyright Companion, 2nd ed. (Buffalo, NY: Hein, 2012); and Kenneth D. Crews, Copyright Law for Librarians and Educators: Creative Strategies and Practical Solutions, 3rd ed. (Chicago: American Library Association, 2011).

34. A law library's implementation of an open source repository is described in Fang Wang, "Building an Open Source Institutional Repository at a Small Law School Library: Is It Realistic or Unattainable?" Information Technology and Libraries 30 (2011): 81.

35. A library's use of interlibrary loan data to make collection development decisions is in Amy Burchfield and Kevin Garewal, "Meeting Evolving Research and Curriculum Needs: A Survey of Interlibrary Loan and OhioLINK Borrowing at an Academic Law Library," Journal of Interlibrary Loan, Document Delivery and Electronic Reserve 19 (2009): 137.

36. "CONTU Guidelines on Photocopying under Interlibrary Loan Arrangements," http://old.cni.org/docs/infopols/CONTU.html. 